\title{
KEBIJAKAN MONETER TANPA BUNGA
}

\author{
Irwan Maulana ${ }^{1}$ \\ irwangravity@gmail.com \\ Ruslan Husein Marasabessy ${ }^{2}$ \\ rully.ief@gmail.com
}

\begin{abstract}
The central bank as the monetary authority uses several monetary instruments including the application of interest rates to create monetary stability. Interest has determined every economic activity, such as consumption, savings, investment, employment opportunities, export-import, and others. This study aims to describe the assumptions of how to conduct monetary policy without interest, using qualitative methods through library research. As for

the background of this research, there are some fatwa in Muslim countries regarding the prohibition of interest while interest as monetary instruments. This research will contribute to the body of existing literature of Islamic economic development.

Keywords: Flowers; Monetary System; Monetary policy
\end{abstract}

\section{Pendahuluan}

Sistem moneter yang berlaku didunia sekarang ini keberadaannya telah ada setelah melalui beberapa masa evolusi. Sistem moneter yang telah berlaku pada masa Nabi Muhammad SAW adalah bimetallic standard dimana emas dan perak (dinar dan dirham) sebagai bagian dari unit moneter yang bersirkulasi secara terus-menerus. Selanjutnya pada abad 16 dikenal sebagai hukum Grasham/ Gresham's Law yang kemudian diadopsi oleh Amerika Serikat pada tahun 1792. Pada tahun 1880 standar internasional dan mayoritas negara-negara dari bimetallic dan silver monometallic beralih kepada standar emas dengan menjadikan emas sebagai basis mata uang mereka. Dibawah standar ini, nilai mata uang sebuah negara secara sah ditentukan dengan berat yang tetap dari emas, dan otoritas moneter berkewajiban mengubah permintaan mata uang domestik kedalam emas yang secara legal telah ditetapkan tingkatnya ${ }^{3}$.

Namun kemudian terjadi krisis di Amerika dan dibatalkannya perjanjian Bretton Wood System pada tahun 1971 adalah awal tidak dibackupnya dollar dengan emas. Sejak itu pula, tidak satupun negara didunia ini memback up mata uangnya dengan emas. Istilah mata uang yang bersifat fiat ini disebut dengan managed money standard. Hal tersebut

\footnotetext{
${ }^{1}$ Dosen Tetap Prodi Perbankan Syariah STAI Asy-Syukriyyah

${ }^{2}$ Dosen Tetap Prodi Muamalah STAI Asy-Syukriyyah

${ }^{3}$ Karim, Adiwarman A (2007) Ekonomi Makro Islam. Jakarta: PT. Raja Grafindo Persada
} 
berakibat pada beberapa hal yang membahayakan stabilitias moneter diantaranya inflasi yang tinggi, nilai tukar yang tidak stabil dan spekulasi yang makin meningkat ${ }^{4}$.

Bank sentral sebagai otoritas moneter menggunakan beberapa instrumen moneter diantaranya penerapan suku bunga untuk menciptakan stabilitas moneter. Menurut Ahmad dalam Chapra ${ }^{5}$ bunga telah menentukan setiap kegiatan ekonomi, seperti konsumsi, tabungan, investasi, kesempatan kerja, ekspor-impor, dan lain-lain. Bunga juga merupakan instrumen utama kebijakan moneter.

Paper ini akan membahas apakah peranan suku bunga yang demikian sentral dalam perekonomian ini bersifat intrinsik atau artifisial yang dikembangkan oleh pihak tertentu yang memiliki kepentingan? Apakah ada alternatif selain bunga atau riba dalam memobilisasi dana dari pemilik dana ke pihak yang membutuhkan dana untuk investasi? Bila digunakan alternatif selain bunga, bagaimana peranan lembaga-lembaga keuangan yang bertanggung jawab atas mobilisasi dana untuk investasi dan sistem moneter?

Dalam penelitian ini metode penelitian yang digunakan adalah metode kualitatif, yaitu alat ukur/alat kualitatif yang digunakan untuk meng-exercise topik/objek penelitian ${ }^{6}$. Penelitian Kualitatif yang mengakumulasi data dasar dalam cara deskriptif, biasanya digunakan istilah penelitian survei ${ }^{7}$.

Penelitian kualitatif memiliki hubungan erat antara ontology (keyakinan), epistomology (ilmu), perspektif teoritis dan metodologi serta metode penelitian. Ada dua sumber ilmu epistemologi Islam yaitu al-Qur'an dan as-Sunnah. Bahkan sumber epistemologi Islam tersebut juga mengafirmasikan sumber ilmu lainnya yaitu berupa akal dan hati serta indra yang terdapat dalam diri manusia ${ }^{8}$.

Adapun alat ukur/alat kualitatif yang digunakan untuk meng-exercise topik/objek penelitian adalah Library Research atau Penelitian Kepustakaan, dilakukan untuk memperoleh dan memahami konsep-konsep dan teori-teori serta ketentuan-ketentuan yang relevan dengan tema dimaksud. Penelitian Kepustakaan, yaitu mencari data yang diperoleh dari literatur-literatur dan referensi yang berhubungan dengan judul penelitian meliputi pengidentifikasian secara sistematik, analisis dokumen-dokumen yang memuat informasi berkaitan

\footnotetext{
${ }^{4}$ Khor, Martin (2000). Globalization and The South: Some Critical Issues. No. 147 April

${ }^{5}$ Chapra, M. Umer, Sistem Moneter Islam, Jakarta : Gema Insani Press, 2000.

${ }^{6}$ Ismal, Rifki (2014). Penelitian Ilmiah: Teori dan Aplikasi Teknis. Materi Presentasi Forum Riset Keuangan Syariah 2014 di Institute Pertanian Bogor

${ }^{7}$ Suryabrata, Sumadi (2015). Metodologi Penelitian (Depok: RajaGrafindo Persada)

${ }^{8}$ Adian Husaini (2013) Filsafat Ilmu: Perspektif Barat dan Islam. Jakarta: Gema Insani
} 


\section{Landasan Teori}

\section{Sistem Moneter}

Menurut Ascarya ${ }^{9}$ terdapat tiga perbedaan utama sistem moneter konvensional dengan Islam. Pertama, penggunaan uang fiat atau uang kertas yang bisa diperdagangkan dalam bursa valuta asing, kemudian ia juga memiliki nilai intrinsik dan ekstrinsik yang berbeda. Nilai instrinsik pada uang merupakan nilai yang terkandung dalam uang, sedangkan nilai ekstrinsik merupakan nilai yang tertera dalam uang tersebut. Sementara dalam Islam, uang merupakan sarana penyimpan nilai (store of value) yang memiliki nilai intrinsik dan ekstrinsik sama seperti dinar dan dirham (fully backed money).

Uang tidak mempunyai harga, tetapi mereflesi harga semua barang, dengan kata lain uang tidak mempunyai kegunaan secara langsung dan dapat membeli barang yang bermanfaat. Dengan kata lain uang bukan dijadikan komoditas untuk diperdagangankan atau sebagai alat spekulasi akan tetapi sebagai fungsi penyimbang transaksi. Jadi penyimbang peredaran uang dan barang ${ }^{10}$. Al-Ghazali berpendapat bahwa tindakan memperdagangkan dinar dan dirham sama halnya memenjarakan uang sehingga tidak lagi berfungsi. Semakin banyak uang diperdagangkan, semakin sedikit yang dapat berfungsi sebagai alat tukar. Jika semua digunakan untuk membeli uang, tidak ada lagi uang yang dapat berfungsi sebagai alat tukar.

Kedua, bunga menjadi ciri utama dalam sistem moneter konvensional. Penetapan suku bunga dicerminkan pada perkembangan suku bunga Pasar Uang Antar Bank Overnight (PUAB O/N). Pergerakan di suku bunga PUAB ini diharapkan akan diikuti oleh perkembangan di suku bunga deposito, dan pada gilirannya suku bunga kredit perbankan. Dengan mempertimbangkan pula faktor-faktor lain dalam perekonomian, Bank sentral pada umumnya akan menaikkan suku bunga apabila inflasi ke depan diperkirakan melampaui sasaran yang telah ditetapkan, dan sebaliknya. Melalui ketetapan suku bunga masyarakat bisa melihat pergerakan nominalnya sehingga bisa menimbulkan kegiatan spekulasi. Sementara bagaimana dalam Islam bagaimana kebijakan moneter tanpa bunga akan dibahas pada paper ini.

\footnotetext{
${ }^{9}$ Ascarya, 2007. "Optimum Monetary Policy under Dual Financial/Banking System.” Paper. Dipresentasikan pada USIM Islamic Economics Conference (IECONS 2007). Kuala Lumpur, Malaysia: Universiti Sains Islam Malaysia, 17-19 Juli.

${ }^{10}$ Karim, Adiwarman A (2001). Ekonomi Islam: Suatu Kajian Kontemporer. Jakarta: Rajawali Pers
} 
Ketiga adalah fractional reserve banking, merupakan sistem perbankan modern yang sarat dengan resiko resesi ekonomi, karena dibangun sebagai wadah finansial semu dan berimplikasi pada bubble economy. Karena sumber instabilitas ekonomi modern pada saat ini terletak pada sistem fractional reserve banking yang diaplikasi di perbankan komersial di seluruh dunia melalui kemampuan penciptaan uang (creation money), sehingga money supply bergeser dari titik keseimbangannya. Melihat fenomena ini, pemikiran ekonomi Islam dan pemikiran ekonomi mazhab Austria bersama-sama menyumbangkan pemikiran kontrusktif terhadap sistem moneter perbankan, yaitu berupa fractional reserve free-banking. Bertujuan untuk penyesuaian penciptaan media fidusia (bank notes dan deposito) dengan permintaan publik. Sehingga diharapkan mampu menyesuaikan jumlah uang beredar dengan permintaan yang lebih efisien ${ }^{11}$.

\section{Pandangan Islam Mengenai Bunga}

Praktek pembungaan uang saat ini telah memenuhi kriteria riba yang terjadi pada zaman Rasulullah SAW, yakni riba nasi'ah. Dengan demikian praktek pembungaan uang termasuk salah satu bentuk riba, dan riba haram hukumnya ${ }^{12}$. Hukum haramnya riba adalah sesuatu yang Qath'i dan tidak ada ulama yang berbeda pandangan tentang hal ini, Allah swt berfirman:

$$
\text { وأحلّ الله البيع و حرّم الرّبا }
$$

Artinya: "padahal Allah telah menghalalkan jual beli dan mengharamkan riba"

\section{(Q.S Al-Baqarah: 275)}

Bunga (interest) adalah imbalan yang dibayar oleh peminjam atas dana yang diterimanya, bunga dinyatakan dalam persen. Bank konvensional dan lembaga keuangan konvensional sebagian besar menggantungkan keuntungannya pada bunga ${ }^{13}$.

Hukum bunga bank sama dengan riba merupakan keputusan seluruh lembaga fatwa baik yang bertaraf internasional maupun nasional, sehingga dikategorikan sebagai Ijma. Ijma Ulama tahun 1965 di Cairo mengharamkan bunga bank dengan di hadiri oleh

\footnotetext{
${ }^{11}$ Ayief Fathurrahman (2015). Fractional Reserve Free-Banking Dalam Perspektif Maslahah: Sebuah Komparasi Pemikiran Ekonomi Islam dan Ekonomi Austria. Jurnal Akademika. Vol. 20 No. 02 JuliDesember

${ }^{12}$ Fatwa Majelis Ulama Indonesia (MUI) No.1 tahun 2004 tentang Bunga (Interest/Fa'idah)

${ }^{13}$ Badri, M. A., Syamhudi, K., Tuasikal, M. A., \& Abu Ahmad Zainal Abidin, L. (2012). Edisi 02/2012Majalah Pengusaha Muslim: Masih Adakah Riba di Bank Syariah? (Vol. 24). Yayasan Bina Pengusaha Muslim.
} 
150 ulama yang berasal dari 35 negara. Pada tahun 1976 M, dalam muktamar ekonomi Islam sedunia di mekkah al-Mukarramah kembali di tegaskan keharaman bunga bank, muktamar ini dihadiri oleh 300 lebih ulama dan ekonom dari seluruh dunia.

Pada tahun 1983 M, Muktamar Bank Syariah sedunia di Kuwait kembali menekankan keharaman bunga bank. Pada tahun 1985 Majma Al Fiqh Al Islami (Divisi Fiqh OKI) memutuskan keharaman bunga bank, baik dari denda dan keterlambatan yang di syaratkan di awal transaksi. Pada tahun 1986 M, Al Majma Al Fiqh Al Islami (Divisi Fiqh Rabithah Alam Islami) menfatwakan segala bentuk bunga pinjaman adalah haram.

Berdasarkan beberapa pandangan dan pemaknaan dan pengklasifikasikan tentang bunga atau riba, maka kebijakan moneter yang berbasis bunga terdapat pada transaksi hutang-piutang yang menggunakan regulasi menaikan suku bunga maupun surat berharga yang menjadi acuan itu semua mengandung unsur bunga. Oleh sebab itu semua instrumen konvensional yang mengandung unsur bunga tidak dapat di gunakan dalam kebijakan moneter syariah.

\section{Pembahasan}

Seakan ekonomi di manapun dan kapanpun tidak lepas dari bunga. Bunga merupakan variabel yang menentukan dalam setiap kegiatan ekonomi. Konsumsi, tabungan, investasi, kesempatan kerja, ekspor-impor, dan lain-lain, dipengaruhi oleh suku bunga. Suku bunga merupakan instrumen utama dalam kebijakan moneter untuk mencapai tujuan ekonomi.

Bahwasanya orang lebih suka memegang aset dalam bentuk likuid dari pada aset piutang karena aset likuid dapat digunakan untuk transaksi dan berjaga-jaga adalah masuk akal. Akan tetapi kompensasi berupa bunga bagi orang yang bersedia merubah aset likuidnya yang dibutuhkan untuk transaksi dan berjaga-jaga menjadi aset piutang dengan alasan bunga itu mendatangkan penghasilan adalah tidak masuk akal. Bila uang sebagai aset likuid itu dibutuhkan untuk transaksi dan berjaga-jaga dan karena transaksi pembelian barang dan jasa dan berjaga-jaga diperlukan untuk hidup maka orang tersebut tidak akan dapat mengalihkan aset likuid tersebut ke aset piutang meskipun akan mendatangkan tambahan penghasilan sebab dengan tindakan pengalihan itu dia tidak lagi memiliki aset likuid yang dibutuhkan untuk transaksi dan berjaga-jaga yang dibutuhkan untuk hidup. Setelah memenuhi kebutuhan untuk transasksi dan berjaga-jaga, orang menggunakan uang 
untuk spekulasi bisa dipahami, tetapi implikasinya bahwa orang bersedia menyerahkan uang untuk dipinjamkan dan kemudian mendapatkan penghasilan berupa bunga karena motif spekulasi perlu dipertanyakan. Motif spekulasi di sini mestinya diartikan bahwa orang bersedia menyerahkan uang untuk digunakan oleh pihak lain dan kemudian dikembalikan lagi dengan nilai yang dapat lebih besar atau lebih kecil dari pada nilai awalnya.

Bentuk yang paling tepat untuk motif spekulasi ini adalah penyertaan uang ini dalam kegiatan investasi yang hasil baliknya (return) berupa bagi untung-rugi (profit-loss sharing) bukan bunga. Uang memang diperlukan untuk kegiatan investasi. Kegiatan investasi bisa menghasilkan keuntungan, dapat juga menderita kerugian karena adanya faktor ketidakpastian (uncertainty) dalam kegiatan investasi atau usaha. Karenanya, hasil balik yang adil bagi uang yang digunakan untuk investasi tadi adalah berupa perolehan bagian keuntungan bila investasi itu untung dan turut menanggung kerugian bila investasi itu rugi, seperti halnya hasil balik bagi pihak yang menjalankan investasi yang mendapatkan keuntungan bila investasinya untung dan menanggung kerugian berupa pengorbanan waktu, keahlian, dan tenaga yang tidak dibayar bila investasinya rugi. Hasil balik berupa bunga dalam pengguaan uang untuk investasi tersebut tidak adil dan karenanya tidak dibenarkan karena pendekatan bunga yang memberikan hasil balik positif yang pasti bagi pemilik uang tanpa mempedulikan untung atau ruginya kegiatan investasi hanya menguntungkan pemilik uang dan belum tentu menguntungkan bahkan bisa merugikan pelaku investasi bila investasi tersebut rugi. Kerugian bagi pelaku investasi itu juga bisa berlipat ganda karena dia bukan hanya menanggung kerugian yang merupakan bagiannya saja tetapi juga menanggung bagian kerugian yang mestinya ditanggung pemilik uang yang justru mendapat keuntungan dalam bentuk anggapan riil tadi yaitu berupa suku bunga.

Inflasi dan ketidakstabilan sektor riil dari waktu ke waktu senantiasa menjadi perhatian rezim pemerintahan yang berkuasa serta otoritas moneter. Hal ini tercermin dari kebijakan otoritas moneter dalam menjaga tingkat inflasi yang harus selalu turun menjadi satu digit atau inflasi moderat. Paradigma berfikir ini menunjukan bahwa inflasi akan terus terjadi, karena paradigma berfikirnya bukan bagaimana inflasi tidak terjadi. Upaya otoritas moneter mengendalikan inflasi memang sangatlah beralasan. Terutama disebabkan dampak inflasi terhadap pertumbuhan ekonomi. Dari segi biayanya, biaya yang harus ditanggung 
pemerintah dengan adanya inflasi sangatlah besar. Secara emperik dampak inflasi terhadap pertumbuhan ekonomi terlihat dari krisis tahun 1997 - 1998 yang mengakibatkan terganggunya sektor riil ${ }^{14}$.

Inti yang menyebabkan turunnya nilai mata uang terhadap barang adalah inflasi. Pertanyaan utama adalah, kenapa terjadi inflasi? Secara teoritis selama ini diketahui ada dua penyebab utama terjadinya inflasi, yaitu tarikan permintaan (demand full inflation) dan desakan biaya (cost push inflation), inflasi yang terjadi di Indonesia lebih banyak terjadi karena desakan biaya dan sistem keuangan serta sistem ekonomi yang berlaku saat ini adalah sistem kapitalis. Kelemahan utama sistem kapitalis saat ini adalah menjadikan uang sebagai komoditi dan alat spekulasi dalam perekonomian. Ketika uang dijadikan sebagai komoditi, maka nilai uang tidak lagi sesuai dengan nilai riil. Inilah penyebab kenapa nilai uang selalu merosot dibandingkan nilai barang. Selain itu, uang juga berfungsi sebagai alat produksi (uang dapat menghasilkan uang) melalui bunga/ interest yang dilakukan oleh bank. Bank merupakan mesin utama dalam sistem ekonomi kapitalis, di samping mesin keduanya adalah pasar modal yang notabene lebih bersifat spekulatif atau judi ${ }^{15}$.

Perbedaan antara mata uang emas dan perak dengan mata uang dari jenis lain adalah tingkat kesulitan atau kemudahan untuk membuat mata uang palsu, jika kebijakan moneter negara mampu mengatur keseimbangan antara jumlah mata uang beredar dengan jumlah barang melalui mekanisme ekonomi riil bukan berbasis bunga yang menyebabkan buble economic, meskipun uang yang digunakan adalah fiat money, inflasi tidak akan terjadi. Bahaya bunga sangat mengancam stabilitas ekonomi, karena ketika bunga dijadikan instrumen utama moneter, maka keseimbangan nilai tukar uang bukan lagi diukur dengan jumlah nilai harga barang dan jasa pada sektor ekonomi riil, namun akan dimainkan oleh otoritas moneter melalui penentuan interest rate.

Metode ini didasarkan atas pandangan bahwa sebagaimana barang dan jasa, permintaan atas uang terdiri atas tiga faktor, permintaan transaksi, permintaan untuk cadangan, dan permintaan untuk berspekulasi. Ketika tingkat suku bunga naik, tentunya kesempatan biaya uang juga akan meningkat, maka orang akan mempersiapkan untuk

\footnotetext{
${ }^{14}$ Hatta M, Telaah Singkat Pengendalian Inflasi Dalam Perspektif Kebijakan Moneter Islam, Jurnal Ekonomi Ideologis, http://www.jurnal-ekonomi.org/2008/06/16/telaah-singkat-pengendalia n-inflasi-dalamperspektif-kebijakan-moneter-islam.

${ }_{15}$ Amri Amir (2011). Redenominasi Rupiah dan Sistem Keuangan, Jurnal Paradigma Ekonomika, Vol. 1, Nomor 4
} 
mengurangi pengeluaran. Dalam kondisi ini, ada hubungan yang negatif antara permintaan uang untuk berspekulasi dengan tingkat suku bunga. Jadi, ketika suku bunga tinggi, maka permintaan uang menurun, meskipun hubungan ini hanya terjadi pada sektor individu, karena pada sektor publik, permintaan atas uang ditentukan oleh kebijakan pemerintah atas belanja keuangan publik serta pajak ${ }^{16}$.

Secara prinsip dalam pelaksanaan kebijakan moneter Islam menurut Chapra berbeda dengan kebijakan moneter konvensional terutama dalam pemilihan target dan instrumennya. Perbedaan yang mendasar antara kedua jenis instrumen tersebut adalah prinsip Islam tidak membolehkan adanya jaminan terhadap nilai nominal maupun rate return (suku bunga). Oleh karena itu, apabila dikaitkan dengan target pelaksanaan kebijakan moneter maka secara otomatis pelaksanaan kebijakan moneter berbasis Islam tidak memungkinkan menetapkan suku bunga sebagai target/sasaran operasionalnya ${ }^{17}$.

Dalam perekonomian Islam, permintaan akan uang terutama muncul dari transaksi dan kebutuhan yang kebanyakan ditentukan oleh tingkat pendapatan dan distribusinya. Permintaan spekulatif akan uang pada dasarnya dipicu oleh fluktuasi tingkat bunga dalam perekonomian kapitalis. Penurunan tingkat bunga yang disertai dengan harapan yang akan meningkat merangsang orang ataupun perusahaan-perusahaan untuk tetap menyimpan uangnya ${ }^{18}$.

Dalam sebuah perekonomian Islam, permintaan terhadap uang akan lahir terutama motif dari transaksi dan tindakan berjaga-jaga yang ditentukan pada umumnya oleh tingkatan uang dan distribusinya.

Motif spekulatif pada dasarnya didorang oleh fluktuasi suku bunga pada perekonomian kapitalis. Suatu penurunan dalam suku bunga dibarengi dengan harapan tentang kenaikannya akan mendorong individu dan dibarengi dengan harapan tentang kenaikannya akan mendorong individu dan perusahaan akan meningkatkan jumlah uang yang dipegang. Karena suku bunga seringkali berfluktuasi pada perekonomian kapitalis. Karena dalam perekonomian kapitalis tingkat bunga seringkali berfluktuasi, uang yang sengaja hanya disimpan akan terus menerus berubah. Penghapusan bunga dan kewajiban

\footnotetext{
${ }^{16}$ Hasan, Kiaee (2007). Monetary Policy in Islamic Economic Framework. Case of Islamic Republic of Iran, Proceeding of the 2nd iECONS2007, Faculty of Economics and Muamalat, Islamic Science University of Malaysia

${ }^{17}$ Chapra, M. Umer, Sistem Moneter Islam, Jakarta : Gema Insani Press, 2000.

${ }^{18}$ Chapra, M. Umer, Islam dan Tantangan Ekonomi, Jakarta : Gema Insani Press, 2000.
} 


\section{Jurnal Asy-Syukriyyah}

membayar zakat sebesar 2,5\% setahun tidak hanya dapat meminimalisasikan permintaan spekulatif akan uang maupun penyimpanan uang yang diakibatkan oleh tingkat bunga diatas, melainkan juga memberi stabilitas yang lebih tinggi terhadap permintaan akan uang.

Hal ini diperkuat dengan sejumlah faktor diantaranya ${ }^{19}$ :

1. Tidak adanya bunga dalam perekonomian Islam menghadapkan pemilik modal pilihan tidak mau mengambil resiko dan tetap mempertahankan uangnya dalam bentuk tunai tanpa imbalan atau menempuh resiko yang telah diperhitungkan terlebih dahulu dan menginvestasikannya dalam bentuk kerjasama bagi hasil dengan beberapa imbalan.

2. Akan tersedia peluang-peluang investasi jangka pendek ataupun jangka panjang kepada semua investor kecil maupun besar yang mau mengambil resiko yang telah diperhitungkan sebelumnya, dengan ini para investor lebih berhati-hati dalam penggunaan uang.

3. Tingkat keuntungan tidak seperti halnya tingkat bunga, tidak akan ditentukan terlebih dahulu, satu-satunya hal yang harus ditentukan terlebih dahulu adalah perbandingan resiko laba-rugi (profit sharing ratio) dan tidak akan berfluktuasi sebagaimana yang terjadi dengan bunga. Kalaupun ada perubahan biasanya ini akan terjadi setelah adanya tekanan dari pasar dan itupun setelah proses negoisasi yang panjang. Jika prospek ekonomi membaik, keuntungan dengan sendirinya akan naik, dengan demikian tidak ada sesuatu yang diperoleh dengan menunggu.

Preferensi likuiditas yang muncul dari motif spekulatif oleh karenanya tidak penting dalam perekonomian Islam. Sehingga variabel yang harus diformulasikan dalam perekonomian Islam adalah stok uang bukan tingkat suku bunga. Bank Islam harus mengarahkan kebijakan moneternya untuk mendorong pertumbuhan dalam penawaran uang yang cukup untuk membiayai pertumbuhan potensial dalam output jangka menengah dan jangka panjang demi mencapai harga yang stabil dan tujuan-tujuan sosio ekonomi Islam. Sasarannya haruslah untuk menjamin bahwa pengembangan moneter yang tidak berlebihan melainkan cukup untuk sepenuhnya dapat mengekploitasi kapasitas perekonomian untuk menawarkan barang dan jasa bagi kesejahteraan sosial umum. Tingkat pertumbuhan yang

\footnotetext{
${ }^{19}$ Chapra, M. Umer, Sistem Moneter Islam, Jakarta : Gema Insani Press, 2000.
} 
ingin dicapai adalah stabil, realistis dan dapat bertahan dalam jangka menengah dan panjang bukan yang realistis naik dan turun ${ }^{20}$.

Meskipun strategi di atas tidak mengakui segi penting pengaturan pertumbuhan uang dalam menajemen perekonomian yang sukses bukan berarti bahwa ini mencerminkan pendekatan moneter yang sederhana dan komitmen terhadap ideologinya. Tidak ada anggapan yang mengatakan bahwa kekuatan pasar saja dapat menghasilakan non inflationary, melenyapkan pengangguran, mengurangi kerugian dan memperjelas pemahaman akan tujuan-tujuan lain jika pertumbuhan uang diatur secara memadai. Sesungguhnya perlu ditekankan bahwa untuk mewujudkan tujuan-tujuan Islam sepenuhnya bukan hanya pembaharuan ekonomi berdasarkan ajaran-ajaran Islam tidak dapat dihindari tetapi perlu juga bagi pemerintah untuk memainkan peranan positif dan semua kebijakan pemerintah termasuk fiskal, moneter dan pendapatan harus menuju arah yang sama.

\section{Kebijakan Moneter Tanpa Bunga}

Perlunya regulasi dari pemerintah berkoordinasi dengan bank sentral terkait kebijakan moneter tanpa bunga. Pertama, menjadikan fungsi uang berjalan dengan baik di tengah masyarakat yaitu sebagai alat pembayaran transaksi dan merefleksikan nilai suatu barang, bukan menjadikan uang sebagai komoditas yang bisa diperjualbelikan. Kedua, kebijakan moneter tanpa bunga dialihkan dengan sistem bagi hasil atau investasi ke sektor riil menggunakan akad-akad muamalah Islam.

Dalam sistem ekonomi, besar kecilnya pembagian keuntungan di sektor moneter ditentukan dari hasil investasi dan pembiayaan yang dilakukan bank di sektor riil. Jika investasi dan produksi di sektor riil berjalan dengan lancar, maka return pada sektor moneter akan meningkat. Sehingga disimpulkan bahwa kondisi sektor moneter merupakan cerminan kondisi sektor riil.

Ketiga, solusi yang harus dilaksanakan sebagai sebuah kebijakan moneter tanpa bunga adalah dengan menjadi penarikan uang yang beredar lebih diarahkan kepada sektor riil dengan menciptakan lapangan pekerjaan baru berupa peningkatan produktivitas dengan cara membuka peluang investasi riil sebagai perimbangan agar jumlah uang yang beredar

\footnotetext{
${ }^{20}$ Hasan, Kiaee (2007). Monetary Policy in Islamic Economic Framework. Case of Islamic Republic of Iran, Proceeding of the 2nd iECONS2007, Faculty of Economics and Muamalat, Islamic Science University of Malaysia
} 
bisa terkontrol dan stabil. Dengan kata lain, permintaan terhadap uang akan lahir terutama dari motif transaksi dan tindakan berjaga-jaga yang ditentukan pada umumnya oleh tingkatan pendapatan, makin besar permintaan akan uang untuk tingkatan pendapatan agregat tertentu.

Hal ini sesuai dengan pendapat Keynes yang mendukung penurunan suku bunga diimbangi dengan kesempatan kerja penuh (full employment). Ia mengatakan jika kesempatan kerja penuh akibat dari investasi yang tinggi maka memerlukan penurunan tingkat bunga jauh dibawah rata-rata.

Selanjutnya, transaksi pertukaran dalam kebijakan moneter harus terfokus pada pertukaran barang dan jasa, sehingga perputaran uang dan barang serta jasa akan menjadi lebih balance tanpa terjadi sebuah ketimpangan dalam hubungan antara perimbangan peredaran uang, barang dan jasa.

Bunga tidak penting dalam perekonomian digambarkan dengan konsep Ekonomi Satu Pulau Satu Orang, Ekonomi Satu Pulau Lima Orang, Ekonomi Satu Pulau Lima Orang dan Uang dari Langit, Ekonomi Satu Pulau Lima Orang Uang dari Langit dan Raja, Ekonomi Banyak Pulau Banyak Orang Banyak Uang Banyak Raja. Kelima konsep tersebut menggambarkan model ekonomi makro dari bentuk yang paling sederhana sampai pada bentuk yang kompleks. Konsep Ekonomi Satu Pulau Satu Orang menggambarkan bahwa orang akan mendapatkan apa yang ia kerjakan sesuai dengan yang ia perbuat, konsep ini berkaitan dengan mengalokasikan waktu bekerja dan waktu istirahat untuk meningkatkan utilitas. Ekonomi Satu Pulau Lima Orang, menggambarkan tentang keadaan ekonomi yang disebt double coincidence needs yaitu pertukaran hanya akan dapat terjadi bila ada keinginan yang cocok antara kedua pihak. Ekonomi Satu Pulau Lima Orang dan Uang dari Langit menggambarkan tentang uang yang beredar dalam ekonomi, kenaikan uang beredar ternyata telah meningkatkan harga masing-masing barang. Ekonomi Satu Pulau Lima Orang, Uang dari Langit dan Raja, konsep ini menggambarkan tentang adanya kepemimpinan dalam mengatur perekonomian yang menyangkut peredaran uang dan Ekonomi Banyak Pulau Banyak Orang Banyak Uang Banyak Raja menggambarkan tentang kepemimpinan yang memiliki cakupan yang luas dengan adanya pemerintah yang mengatur peredaran uang untuk orang banyak. Ia menggambarkan sebuah model dimana pasar diasumsikan kompetitif, maka real return on capital sama dengan marginal product of capital yang diformulasikan dengan MPk $=\mathrm{r}$. Secara singkat model ini merupakan contoh 
bagaimana suatu model makro ekonomi yang kompleks dibangun dengan menggunakan pendekatan mikro ekonomi, dan memberi penekanan bahwa bunga bukanlah suatu yang perlu dan penting dalam mengembangkan suatu model ekonomi ${ }^{21}$.

Bank sentral sebagai regulator, bisa menggunakan variabel cadangan devisa, bukan suku bunga ${ }^{22}$. Bank sentral harus menggunakan kebijakan moneternya untuk menghasilkan suatu pertumbuhan dalam sirkulasi uang yang mencukupi untuk membiayai pertumbuhan potensial dalam output selama periode menengah dan panjang, dalam kerangka harga-harga yang stabil dan sasaran sosioekonomi lainnya. Tujuannya untuk menjamin ekspansi moneter yang pas, tidak terlalu lambat tetapi juga tidak terlalu cepat, tetapi cukup mampu menghasilkan kesejahteraan yang merata bagi masyarakat. Laju pertumbuhan yang dituju haruslah yang bersifat kesinambungan, realistis serta mencakup jangka menengah dan jangka panjang.

Terakhir, peluang dalam penerapan kebijakan moneter tanpa bunga perlu dukungan dalam pemahaman serta kesadaran masyarakat muslim yang mempunyai aturan yang sudah digariskan dalam nash mengenai keuangan yang mungkin kebijakan moneter lebihnya berada di tangan pemerintah sebagai regulator, yang saat ini masih mengalami hambatan dalam kebijakan moneter yang Islami, akan tetapi kebangkitan keuangan secara syariah bukan ditentukan oleh kebijakan makro, tetapi perindividu muslim sangat menentukan sehingga dia bukan sekedar akan menjadi sebuah wacana, aktivitas dalam keuangan sehari-hari bahkan ia akan menjadi sebuah inspirasi kebijakan makro khususnya di bidang moneter.

\section{Kesimpulan}

Bahwasanya suku bunga mempunyai peranan yang sangat penting dalam kegiatan ekonomi terutama dalam mobilisasi dana tabungan untuk investasi dan sebagai instrumen utama kebijakan moneter hanyalah mitos dan artifisial yang dikembangkan oleh kaum kapitalis untuk mempertahankan dominasinya dalam perekonomian. Pentingnya peranan suku bunga dibangun oleh teori-teori seperti time-preference theory, liquidity preference theory, interest and deposit mobilization, bunga sebagai harga kelangkaan dari modal,

\footnotetext{
${ }^{21}$ Adiwarman A Karim ((2013). Bank Islam: Fiqih dan Keuangan. Jakarta: PT. Raja Grafindo Persada. Hal $29-41$

${ }^{22}$ Mustafa Edwin Nasution, dkk (2007). Pengenalan Eksklusif Ekonomi Islam. Jakarta: Kencana
} 


\section{Jurnal Asy-Syukriyyah}

opportunity cost of capital, bunga untuk mengimbangi penurunan nilai uang karena Inflasi, dan bunga sebagai keuntungan yang tidak punyai dasar yang kuat.

Penerapan suku bunga dalam perekonomian ini menimbulkan alokasi sumber finansial yang tidak efisien, ketidakadilan dalam akses untuk investasi, distribusi, dan konsumsi; ketimpangan antara sektor finansial dan sektor riil, dan ketidakstabilan ekonomi. Sistem bunga dalam mobilisasi dana tabungan untuk investasi ini harus diganti dengan qard hasan, murabahah, dan pendanaan yg berkeadilan (equity financing). Equity financing meliputi mudharabah, syirkah, dan kepemilikan saham. Mobilisasi dana ini dilakukan oleh bank komersial yang menerapkan prinsip syariah. Bank komersial Islam mengumpulkan dana dari simpanan biasa (demand deposit), tabungan mudharabah dan deposito mudharabah, serta saham. Dana ini digunakan untuk menyediakan uang tunai bagi nasabah, sebagai cadangan wajib, proyek pemerintah, dan investasi dalam bentuk mudharabah,syirkah, saham, leasing, dan murabahah. Bank sentral melakukan kebijakan moneter untuk mencapai tujuan ekonomi tanpa menggunakan instrumen suku bunga ${ }^{23}$.

${ }^{23}$ Al-Maqrizi (2007), Ighatsah al-Ummah bi Kasyfi al-Ghummah, al-Haram: 'Ain al-Dirasat wa al-Buhu ts al-Insaniyah wa al-Ijtima'iyah 


\section{DAFTAR PUSTAKA}

Al-Maqrizi, Ighatsah al-Ummah bi Kasyfi al-Ghummah, al-Haram: 'Ain al-Dirasat wa alBuhu ts al-Insaniyah wa al-Ijtima'iyah

Amri Amir (2011). Redenominasi Rupiah dan Sistem Keuangan, Jurnal Paradigma Ekonomika, Vol. 1, Nomor 4

Antonio, Muhammad Syafi'I (2001). Bank Syariah Dari Teori Ke Praktek. Jakarta: Gema Insani Press

Ascarya, 2007. "Optimum Monetary Policy under Dual Financial/Banking System." Paper.

Dipresentasikan pada USIM Islamic Economics Conference (IECONS 2007). Kuala Lumpur, Malaysia: Universiti Sains Islam Malaysia, 17-19 Juli.

Badri, M. A., Syamhudi, K., Tuasikal, M. A., \& Abu Ahmad Zainal Abidin, L. (2012). Edisi 02/2012-Majalah Pengusaha Muslim: Masih Adakah Riba di Bank Syariah? (Vol. 24). Yayasan Bina Pengusaha Muslim.

Chapra, M. Umer, Sistem Moneter Islam, Jakarta : Gema Insani Press, 2000.

Chapra, M. Umer, Islam dan Tantangan Ekonomi, Jakarta : Gema Insani Press, 2000.

Edwin Nasution, Mustafa dkk (2007). Pengenalan Eksklusif Ekonomi Islam. Jakarta:

Kencana

Fathurrahman, Ayief (2015). Fractional Reserve Free-Banking Dalam Perspektif

Maslahah: Sebuah Komparasi Pemikiran Ekonomi Islam dan Ekonomi Austria.

Jurnal Akademika. Vol. 20 No. 02 Juli-Desember

Fatwa Majelis Ulama Indonesia No.1 Tahun 2004

Hatta M, Telaah Singkat Pengendalian Inflasi Dalam Perspektif Kebijakan Moneter Islam,

Jurnal Ekonomi Ideologis, http://www.jurnal-ekonomi.org/2008/06/16/telaahsingkat-pengendalia n-inflasi-dalam-perspektif-kebijakan-moneter-islam.

Husaini Adian (2013). Filsafat Ilmu: Perspektif Barat dan Islam. Jakarta: Gema Insani Ismal, Rifki (2014). Penelitian Ilmiah: Teori dan Aplikasi Teknis. Materi Presentasi Forum Riset Keuangan Syariah 2014 di Institute Pertanian Bogor

Karim, Adiwarman A (2001). Ekonomi Islam: Suatu Kajian Kontemporer. Jakarta: Rajawali Pers

Karim, Adiwarman A (2007) Ekonomi Makro Islam. Jakarta: PT. Raja Grafindo Persada 


\section{Jurnal Asy-Syukriyyah}

Karim, Adiwarman A (2013). Bank Islam: Fiqih dan Keuangan. Jakarta: PT. Raja Grafindo Persada

Khor, Martin (2000). Globalization and The South: Some Critical Issues. No. 147 April

Kiaee Hasan (2007). Monetary Policy in Islamic Economic Framework. Case of Islamic Republic of Iran, Proceeding of the 2nd iECONS2007, Faculty of Economics and Muamalat, Islamic Science University of Malaysia

Suryabrata, Sumadi (2015). Metodologi Penelitian (Depok: RajaGrafindo Persada)

Tarmizi, Erwandi (2017). Harta Haram Muamalat Kontemporer. Jakarta: PT Erwandi Tarmizi Konsultan. 